\title{
Morpho-Molecular Characterization of Two Ampelomyces spp. (Pleosporales) Strains Mycoparasites of Powdery Mildew of Hevea brasiliensis
}

\author{
Kapila K. Liyanage ${ }^{1,2,3,4}$, Sehroon Khan ${ }^{2,3}$, Siraprapa Brooks ${ }^{1}$, Peter E. Mortimer ${ }^{2,3}$, \\ Samantha C. Karunarathna ${ }^{2,3}$, Jianchu $\mathrm{Xu}^{2,3 *}$ and Kevin D. Hyde ${ }^{1,2}$ \\ 1 Center of Excellence in Fungal Research, and School of Science, Mae Fah Luang University, Chiang Rai, Thailand, \\ ${ }^{2}$ Center for Mountain Ecosystem Studies, Kunming Institute of Botany, Chinese Academy of Sciences, Kunming, China, \\ ${ }^{3}$ World Agroforestry Centre, East and Central Asia, Kunming, China, ${ }^{4}$ Rubber Research Institute of Sri Lanka, Agalawatta, \\ Sri Lanka
}

Powdery mildew disease of rubber affects immature green leaves, buds, inflorescences, and other immature tissues of rubber trees, resulting in up to $45 \%$ losses in rubber latex yield worldwide. The disease is often controlled by dusting the diseased

OPEN ACCESS

Edited by: Raffaella Balestrini, Consiglio Nazionale delle Ricerche (CNR), Italy

Reviewed by:

Claudio Altomare, Consiglio Nazionale delle Ricerche (CNR), Italy

Luana Giordano, Università degli Studi di Torino, Italy

*Correspondence: Jianchu Xu jxu@mail.kib.ac.cn

Specialty section: This article was submitted to Fungi and Their Interactions,

a section of the journal

Frontiers in Microbiology

Received: 01 September 2017 Accepted: 05 January 2018 Published: 19 January 2018

Citation:

Liyanage KK, Khan S, Brooks S, Mortimer PE, Karunarathna SC, XU J and Hyde KD (2018)

Morpho-Molecular Characterization of Two Ampelomyces spp. (Pleosporales) Strains Mycoparasites of Powdery Mildew of Hevea brasiliensis. Front. Microbiol. 9:12. doi: 10.3389/fmicb.2018.00012 plants with powdered sulfur, which can have long-term negative effects on the environment. Therefore, it is necessary to search for alternative and environmentally friendly control methods for this disease. This study aimed to identify mycoparasites associated with rubber powdery mildew species, and characterize them on the basis of morpho-molecular characteristics and phylogenetic analyses of ITS rDNA regions. We observed that the Ampelomyces fungus parasitizes rubber powdery mildew, and eventually destroys it. Furthermore, on the basis of phylogenetic analyses and morphological characteristics we confirmed that the Ampelomyces mycoparasite isolated from rubber powdery mildew is closely related to other mycohost taxa in the Erysiphe genus. A total of 73 (71 retrieved from GenBank and two obtained from fresh collections of rubber powdery mildew fungi) Ampelomyces spp. were analyzed using ITS rDNA sequences and 153 polymorphic sites were identified through haplotypic analyses. A total of 28 haplotypes $(\mathrm{H} 1-\mathrm{H} 28)$ were identified to have a complex network of mutation events. The results from phylogenetic tree constructed on the basis of maximum likelihood analyses, and the haplotype network tree revealed similar relationships of clustering pattern. This work presents the first report on morphomolecular characterization of Ampelomyces species that are mycoparasites of powdery mildew of Hevea brasiliensis.

Keywords: Erysiphe, haplotype, morphology, mycohost, mycoparasite

\section{INTRODUCTION}

Powdery mildew disease devastates rubber [Hevea brasiliensis (Willd. Ex A. Juss.) Müll. Arg.] harvests worldwide (Beeley, 1933; Mitra and Mehta, 1938; Limkaisang et al., 2005). Infection results in a secondary leaf fall of the young leaves that emerged after wintering (Fernando, 1971; Min et al., 2012). The causal agent of powdery mildew disease of rubber trees was first described as 
Oidium heveae by Steinmann (1925). Later, Limkaisang et al. (2005), Takamatsu et al. (2007), and Liyanage et al. (2017) discovered that plurivorous Erysiphe quercicola (S. Takam. and U. Braun), which was known to cause powdery mildew in several other tree species, also infects rubber plants. Powdery mildew disease can result in the loss of up to $45 \%$ of latex yields, reduced girthing-up of the young rubber trees, and slower bark renewal after harvesting (Fernando, 1971; Min et al., 2012; Liyanage et al., 2016). Furthermore, according to Fernando (1971), the flowers of the rubber tree are especially susceptible to powdery mildew, and infection can damage the growth of fruit pods and cause seed loss of up to $90-100 \%$.

Currently, chemical application is the main method to control this rubber tree disease and most commonly used fungicide is sulfur dust (Murray, 1930; Lim, 1982; De S Liyanage and Kuruvilla, 1992; Jayasinghe and Jayaratne, 1997; Tang, 2005). During the process of sulfur dusting, disease control is achieved by blowing powdered sulfur into the rubber tree canopy four to seven times at intervals of 7 days (De S Liyanage and Kuruvilla, 1992; Jayasinghe and Jayaratne, 1997; Priyadarshan et al., 2005). Sulfur does not kill the fungus on the leaf, but protects the leaf from fresh infections (Jayasinghe, 2001). Therefore, the mycelium already on the leaf continues its life cycle, and frequent applications at precise intervals are necessary for effective control of the disease. Applying sulfur dust is expensive, labor intensive, environmentally hazardous and time-consuming, and enormous quantities of sulfur are required worldwide every year (De S Liyanage and Kuruvilla, 1992). The cost of sulfur and other chemical fungicides, and their long-term effects on the environment and human health, necessitate the development of alternative methods for controlling powdery mildew disease.

Biological control agents (BCAs) have the potential to provide alternative methods of preventing or suppressing powdery mildew in some crops (Kiss, 2003). Bio-fungicidal products such as AQ10 Biofungicide ${ }^{\circledR}$, Q-fect, Powdercare ${ }^{\circledR}$, and Sporodex ${ }^{\circledR}$ have been registered and are available in some countries (Kiss, 2003; Park et al., 2010). Several antagonistic fungi from different families have been tested against powdery mildew in other crops, but not yet in rubber plantations. An application of aqueous solutions of Acremonium byssoides W. Gams and T. M. Lim has been shown to control powdery mildew disease on rubber trees. However, very little is known about the natural occurrence and activity of $A$. byssoides on rubber trees (Kiss, 2003; Liyanage et al., 2016). Ampelomyces quisqualis Ces. is a well-known parasite of powdery mildews which is widely distributed throughout the world. A. quisqualis is able to penetrate the hyphae of powdery mildew fungi growing internally from cell to cell through the septal pores. Ampelomyces quisqualis then produces pycnidia (fruiting bodies) intracellularly in the hyphae, conidiophores and immature ascomata of their mycohosts, inhibiting conidial production and cleistothecial (closed fruiting bodies of powdery mildews) development (Emmons, 1930; Speer, 1978; Hashioka and Nakai, 1980; Kiss et al., 2004). The pycnidia help to the fungus to overwinter and produce spores. In terms of long-term exposure, the spores of mycoparasites are unlikely to remain viable for long periods of time. Thus, for successful germination, the spores need both favorable conditions (high humidity or moisture and temperatures of $25^{\circ} \mathrm{C}$ ) and the presence of the appropriate host. Without the host, viability is lost within a few days (Mhaskar and Rao, 1974; Szentiványi and Kiss, 2003; Kiss, 2008; Angeli et al., 2011). However, Jarvis and Slingsby (1997), and Angeli et al. (2011) pointed out that A. quisqualis can survive and infective to powdery mildews even at temperatures below $12^{\circ} \mathrm{C}$. Although genetic diversity of Ampelomyces spp. in different mycohost groups has been formerly documented, the single name $A$. quisqualis is still applied to all pycnidial fungi hyperparasites of powdery mildew (Mhaskar and Rao, 1974; Belsare et al., 1980; Kiss and Vajna, 1995; Kiss, 1997). Park et al. (2010) conducted a phylogenetic study using 254 A. quisqualis isolates, and showed that Ampelomyces hyperparasites are indeed an assemblage of several distinct lineages rather than a single species. The correlation between Ampelomyces isolates and their mycohosts is not clear. Although, they do not show exact host specificity, most of the Ampelomyces isolates showed adaptation to their mycohosts during the evaluation as a hyperparasite. Also, Kiss (1997), Kiss and Nakasone (1998), and Szentiványi et al. (2005) showed that Ampelomyces isolates were mainly divided into two separate clades, each of which was characterized by fast or slow growing in isolated cultures. These authors imply that fast growing Ampelomyces isolates should be reclassified as Phoma glomerata (Corda) Wollenw. and Hochapfel based on the results of molecular analysis and differences in pycnidia formation (Sullivan and White, 2000; Szentiványi et al., 2005). In recent classification by Chen et al. (2015) Phoma glomerata was grouped under the genus Didymellaceae and renamed as Didymella glomerata (Corda) Qian Chen and L. Cai.

Therefore, this study aims to clarify the taxonomic positions of Ampelomyces mycoparasitic fungi through morphological examination, morpho-molecular, and phylogenetic analyses. This work will be a ground base for future work in developing BCAs against powdery mildew disease of rubber trees.

\section{MATERIALS AND METHODS}

\section{Sample Collection}

Leaves, buds and the inflorescences of the rubber tree infected with powdery mildew were collected from different major rubber growing areas in Jinghong, Yunnan, China $\left(21^{\circ} 59^{\prime} 52.54^{\prime \prime} \mathrm{N}\right.$ and $100^{\circ} 46^{\prime} 17.17^{\prime \prime} \mathrm{E}$ ), Matugama, Nivitigalakele, Sri Lanka $\left(6^{\circ} 30^{\prime} 44.35^{\prime \prime} \mathrm{N}\right.$ and $\left.80^{\circ} 7^{\prime} 5.04^{\prime \prime} \mathrm{E}\right)$, and Muang, Chiang Rai, Thailand $\left(20^{\circ} 2^{\prime} 43.98^{\prime \prime} \mathrm{N}\right.$ and $\left.99^{\circ} 53^{\prime} 34.63^{\prime \prime} \mathrm{E}\right)$. Three samples per tree were collected from 10 trees at five different sites where the occurrence of disease was very high from each country discussed above. However, only leaf samples were used for further research. Fresh materials were wrapped in a sterilized moist paper towel, sealed in zip-lock plastic bags, and stored at $5^{\circ} \mathrm{C}$ soon after returning to the laboratory. The Ampelomyces spp. infected leaves collected from China were incubated in plant growth chamber for 2 weeks at $25 \pm 2{ }^{\circ} \mathrm{C}(70 \% \mathrm{RH})$ under 8:16 dark to light ratio. The growth of Ampelomyces spp. and the devastation of the powdery mildew of rubber were photographed every day for time period of 2 weeks. 


\section{Morphological Examination}

Surface structures from leaves were stripped off using doublesided clear adhesive tape as described by Cook et al. (1997), and mounted with the specimen's surface uppermost in an aqueous potassium hydroxide solution (3\%) for examination under a compound microscope. Pycnidia were examined by simply pressing a slide against an infected leaf and by simply sticking an infected leaf to a slide with double-sided adhesive tape. Melzer's reagent (chloral hydrate $100 \mathrm{~g}$, potassium iodide $5 \mathrm{~g}$, iodine $1 \pm 0.5 \mathrm{~g}$, distilled water $100 \mathrm{ml}$ ) was used as a mounting medium for dried material. Photographs were taken by a Canon digital camera fitted to a Nikon 80i compound microscope. Micro-morphological data such as the size and shape of the pycnidia, conidia, and other micro-structures were recorded, along with the growth habits of the mycelium. All macro-morphological observations and photographs were carried out at different magnifications such as $200 \times, 400 \times$, and $1000 \times$. Measurements were made with the Tarosoft (R) Image Frame Work program, and the images were processed with Adobe Photoshop software (Adobe Systems, Inc., United States). Pycnidia of Ampelomyces species were isolated from powdery mildew infected rubber tree leaves by transferring them with glass needles into Petri plates containing Potato Dextrose Agar (PDA) (20 g dextrose, $15 \mathrm{~g}$ agar, and $4 \mathrm{~g}$ potato starch) supplemented with $2 \%$ malt extract and $0.5 \%$ chloramphenicol (Sigma-Aldrich, St. Louis, MO, United States), and cultured at $25^{\circ} \mathrm{C}$ using a 12 -hour cycle of fluorescent illumination.

To observe the surface features at higher magnification on fresh material, $0.5 \mathrm{~cm}$ squares were cut out of the leaf lamina and mounted for cryomicroscopy in the SEM. The fragments were mounted on aluminum stubs with double-sided adhesive tape, coated with gold palladium, and then observed under a SEM (Hitachi S4800) (Cook et al., 1997). All micromorphological observations were carried out at magnifications of up to $12,000 \times$ level.

\section{Fungal DNA Extraction, PCR Amplification, and Sequencing}

For the fungal molecular study, ITS regions of rRNA genes were sequenced from the pycnidia of fungal isolates collected from China. Total DNA was extracted from the mycelia by the Chelex method (Walsh et al., 1991; Hirata and Takamatsu, 1996; Limkaisang et al., 2005). The PCR was performed in a Thermal Cycler in a total volume of $25 \mu \mathrm{l}$. The PCR mixtures contained Taq DNA polymerase $0.15 \mu \mathrm{l}, 2.5 \mu \mathrm{l}$ of $2 \times$ PCR buffer with $2.5 \mu \mathrm{l}$ of dNTPs, $1.6 \mu \mathrm{l}$ of $25 \mathrm{mM} \mathrm{MgCl}_{2}, 1 \mu \mathrm{l}$ of each primer, 50-100 ng of DNA template and the balance amount of doubledistilled water. The genomic rDNA ITS region was amplified by using primers ITS5 (5'-GGAAGTAAAAGTCGTAACAAGG-3') and P3 (5'-CTATTGCTTGATTGTCTCC-3') and both strands of the amplicons were sequenced by using the primers ITS1, ITS4, ITS5, and P3 (White et al., 1990; Kusaba and Tsuge, 1995; Hirata and Takamatsu, 1996). The PCR amplicons were electrophoresed on $1.5 \%$ agarose gels in TAE buffer. The desire bands were purified from the gel, and amplified fragments were sent to a commercial sequencing provider (Tao Yang, Beijing, China). The nucleotide sequence data acquired were deposited in GenBank.

\section{Phylogenetic Analyses}

The closest taxa to our samples were determined with standard nucleotide blast searches against the nucleotide database in GenBank ${ }^{1}$. Analysis of ITS in the closest taxa in the genus Ampelomyces was used to confirm the phylogenetic placement within the genus. The Phoma sp. (GenBank Accession number AY663825) was selected as the outgroup taxon based on Park et al. (2010). Multiple sequence alignments were generated with MAFFT v. 7.036 (Katoh and Standley, 2013), and adjusted manually using BioEdit v. 7.2 (Hall, 1999) and ClustalX (Kohli and Bachhawat, 2003). The maximum-likelihood (ML) analysis was performed in RAxML (Stamatakis, 2006) implemented in raxmlGUI v.0.9b2 (Silvestro and Michalak, 2012). Maximum parsimony (MP) analysis was carried out using PAUP (Phylogenetic Analysis Using Parsimony) v. 4.0b10 (Swofford, 2002). Descriptive tree statistics for parsimony (Tree Length [TL], Consistency Index [CI], Retention Index [RI], Relative Consistency Index [RC], and Homoplasy Index [HI]) were calculated for trees generated under different optimality criteria. The Kishino-Hasegawa tests (Kishino and Hasegawa, 1989) were performed to determine whether the trees inferred under different optimality criteria were meaningfully different.

\section{Haplotypes Identification}

The rRNA ITS sequences were assembled and edited in Sequencher 5.0 (Gene Codes, Co., United States). Sequences were aligned with the MUSCLE algorithm (Edgar, 2004). The haplotype of ITS sequences was defined using DnaSP v5.10 (Librado and Rozas, 2009), and the network tree of haplotypes was generated by Network v4.6.1.3 (Fluxus Technology, Ltd.) with the median-joining method (Bandelt et al., 1999).

\section{RESULTS}

\section{Morphological Study}

All the leaf, flower and buds samples collected from 5 different sites in China were infected with Ampelomyces spp., and no infection was observed in the samples collected from other countries. Although Ampelomyces spp. has not previously been recorded as parasitizing rubber powdery mildew fungus, light microscopic (LM) observation of rubber powdery mildew colonies clearly showed that specimens collected from China were infected by Ampelomyces spp. (Figures 1a-d, 2c). Mycelia of Ampelomyces spp. were superficial or immersed, hyaline, branched, septate (Figures 2f,g). Conidiomata were pycnidial and measured (32-49) $\times(19-32) \mu \mathrm{m}(\overline{\mathrm{x}} 39.2 \times 26.5 \mu \mathrm{m}$, $n=30)$ with a $1.6-2.5$ length/width ratio. They produced pycnidia intracellularly, in the hyphae, conidiophores and immature ascomata (Figures 2a,b,e). The pycnidia were separate, globose, or elongated to pyriform, unilocular, one-cell thick cell wall, of pale brown angular textured (Figures 2a,b,e). No

\footnotetext{
${ }^{1}$ http://www.ncbi.nlm.nih.gov/
} 

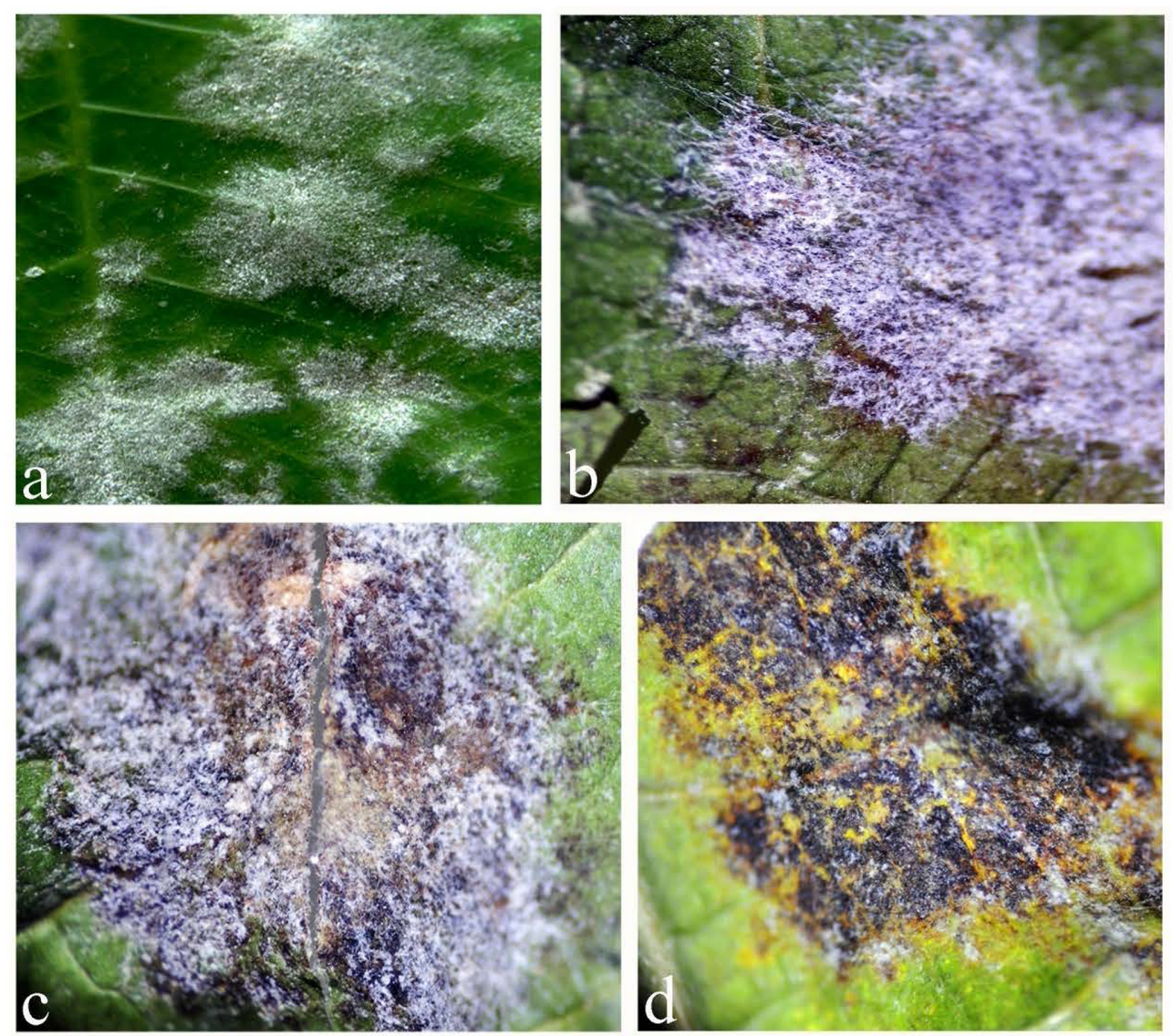

FIGURE 1 | Different stages of Ampelomyces spp. infection of powdery mildew fungal colonies: (a) healthy colonies of powdery mildew on the surface of rubber leaf; (b) powdery mildew colonies infected with Ampelomyces spp. (the brown color spots are the pycnidia produced by Ampelomyces); (c) powdery mildew colonies partially destroyed by Ampelomyces spp.; (d). powdery mildew colonies totally destroyed by Ampelomyces, 1-2 weeks after infection.

distinct ostiole was present and dehisced by apical rupture of pycnidium. Conidiophores were absent. Conidia were (510) $\times(2.4-3.5) \mu \mathrm{m}(\overline{\mathrm{x}}=6.5 \times 2.9 \mu \mathrm{m}, n=35)$ with a $2.1-$ 4.1 length/width ratio. Conidia were very pale brown, aseptate, thin-walled, smooth, guttulate, straight, or curved, cylindrical to fusiform. (Figures 2d,h) Single-spore cultures grew slowly on PDA and took about $10-15$ days, but sporulated profusely.

\section{Phylogenetic Analyses}

Due to the limited availability of sequence data for different genes in selected taxa in the GenBank, only ITS sequence data were used for these analyses. The data set was comprised of 73 sequences: 71 sequences retrieved from GenBank and 2 sequences from our samples infected with rubber powdery mildew (Table 1). To confirm the phylogenetic placement of Ampelomyces spp. identified in the present work, ML analyses and MP were carried out. This analyses comprised 512 total characters, of which 323 were constant, 133 were parsimonyinformative and 56 parsimony-uninformative. One parsimonious tree was generated (Figure 3) and Bootstrap support (BS) values of MP (in red) and ML (in black) is shown on the upper branches (equal to or above $60 \%$ based on 1000 replicates).
The Kishino-Hasegawa test showed that length $=300$ steps with $C I=0.79, R I=0.98, R C=0.78$, and $H I=0.21$. The strains of Ampelomyces spp. on rubber powdery mildew grouped in Clade I, which includes different haplotypes infecting on Erysiphe, with relatively high (100\%) bootstrap support (Figure 3).

\section{Haplotypes Identification}

The alignment of 73 sequences of the ITS rDNA from Ampelomyces spp. were generated from the MUSCLE algorithm (Edgar, 2004). The ITS rDNA sequences of selected specimens from GenBank and two sequences from fresh isolates from rubber powdery mildew were $503 \mathrm{bp}$ long and all contained 153 polymorphic sites. A total of 28 haplotypes ( $\mathrm{H} 1-\mathrm{H} 28)$ were identified with a very complex network of mutation events (Table 1 and Figure 4).

\section{DISCUSSION AND CONCLUSION}

In the present work, we identified for the first time Ampelomyces spp. parasitic on powdery mildew fungi of rubber. In the leaves 

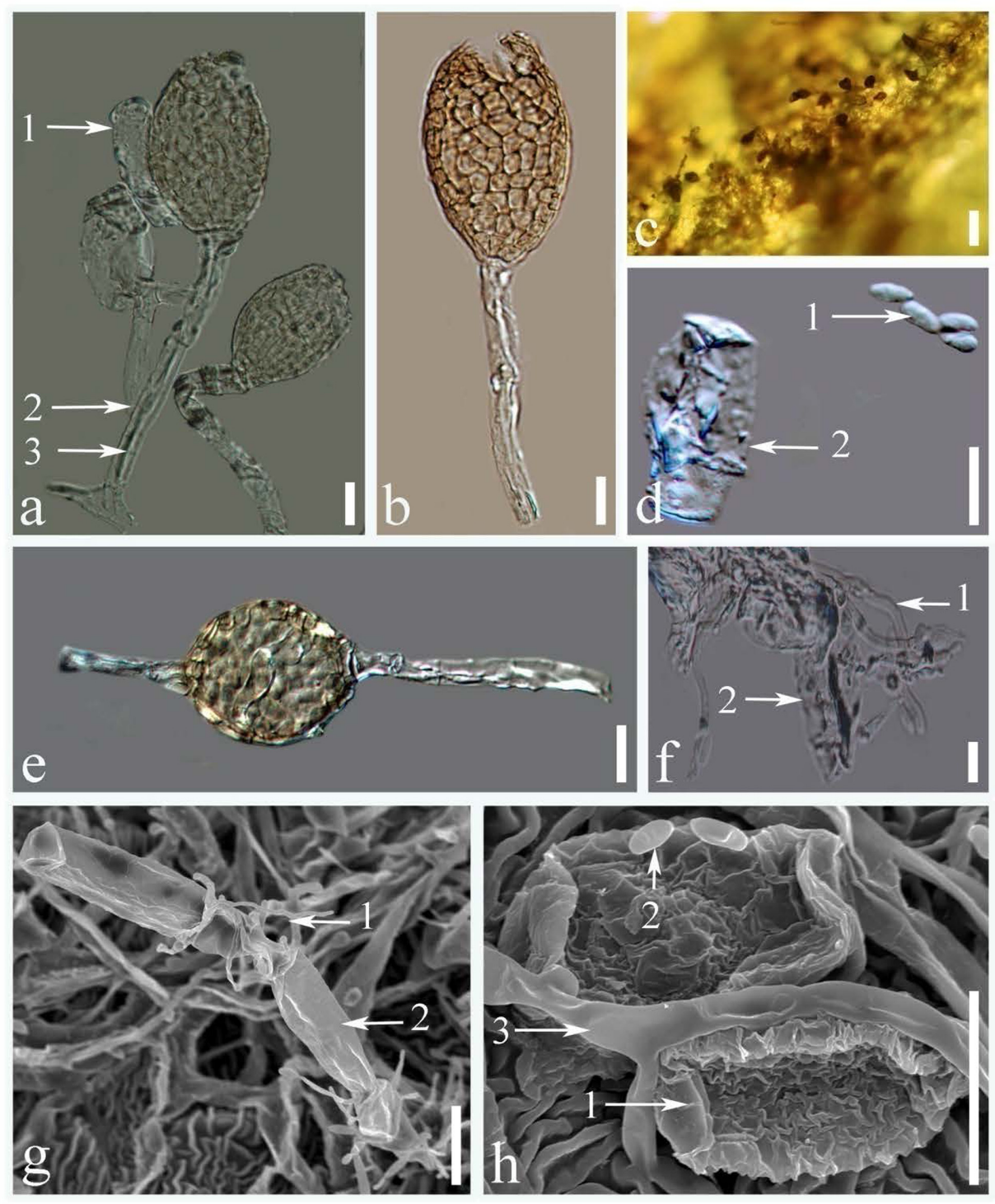

FIGURE 2 | Microstructures of Ampelomyces spp.: (a) pycnidia produced in the conidiophores of rubber powdery mildews (1. conidia of rubber powdery mildew; 2. conidiophores of rubber powdery mildew; 3. intracellular hyphae of Ampelomyces spp.); (b) dehisced pycnidium by apical rupture; (c) pycnidium on the surface of a rubber leaf; (d) conidia (1. conidia of Ampelomyces spp.; 2. conidia of rubber powdery mildew); (e) pycnidia produced inside the hyphae of rubber powdery mildews; (f) superficial mycelium mat (1. mycelium of Ampelomyces spp.; 2. mycelium of rubber powdery mildew); (g) superficial growth of Ampelomyces mycelium on catanate type of conidia in rubber powdery mildew (1. mycelium of Ampelomyces spp.; 2. catanated conidiospore of rubber powdery mildew); (h) mycelium and spores of Ampelomyces spp. (1. non-catenate conidia (Erysiphe quercicola); 2. conidia of Ampelomyces spp., 3. mycelium of Ampelomyces spp.) (Scale bars:

figures $\mathbf{a}, \mathbf{b}, \mathbf{d}-\mathbf{h}=10 \mu \mathrm{m}$, figure $\mathbf{c}=20 \mu \mathrm{m})$.

samples collected, after 1-2 weeks incubation in growth chamber, the Ampelomyces spp. had devastated the powdery mildew colonies, leaving only the lesions created by the powdery mildews (Figure 1). This indicates that Ampelomyces spp. have the potentials to control rubber powdery mildew disease. However, further research on isolation, purification, and inoculation is required to confirm the biocontrol potentials of Ampelomyces spp. Furthermore, it was determined that the samples of leaves, inflorescences, and buds collected from China were found to be infected by Ampelomyces species. These results showed that the Ampelomyces spp. have much favorable weather conditions to propagate and devastate the rubber mildew in China as compared to the other countries. It could be the availability of Ampelomyces spp. spores in China as compared to other countries or may be the evolutionary behavior of the Ampelomyces spp. in China. LM and SEM analysis showed that most of the morphological features of Ampelomyces spp. were similar to other species that infect several distinct lineages of mycohost, but with some modification in the size, shape and color of pycnidia and spores. The mycelia of Ampelomyces 


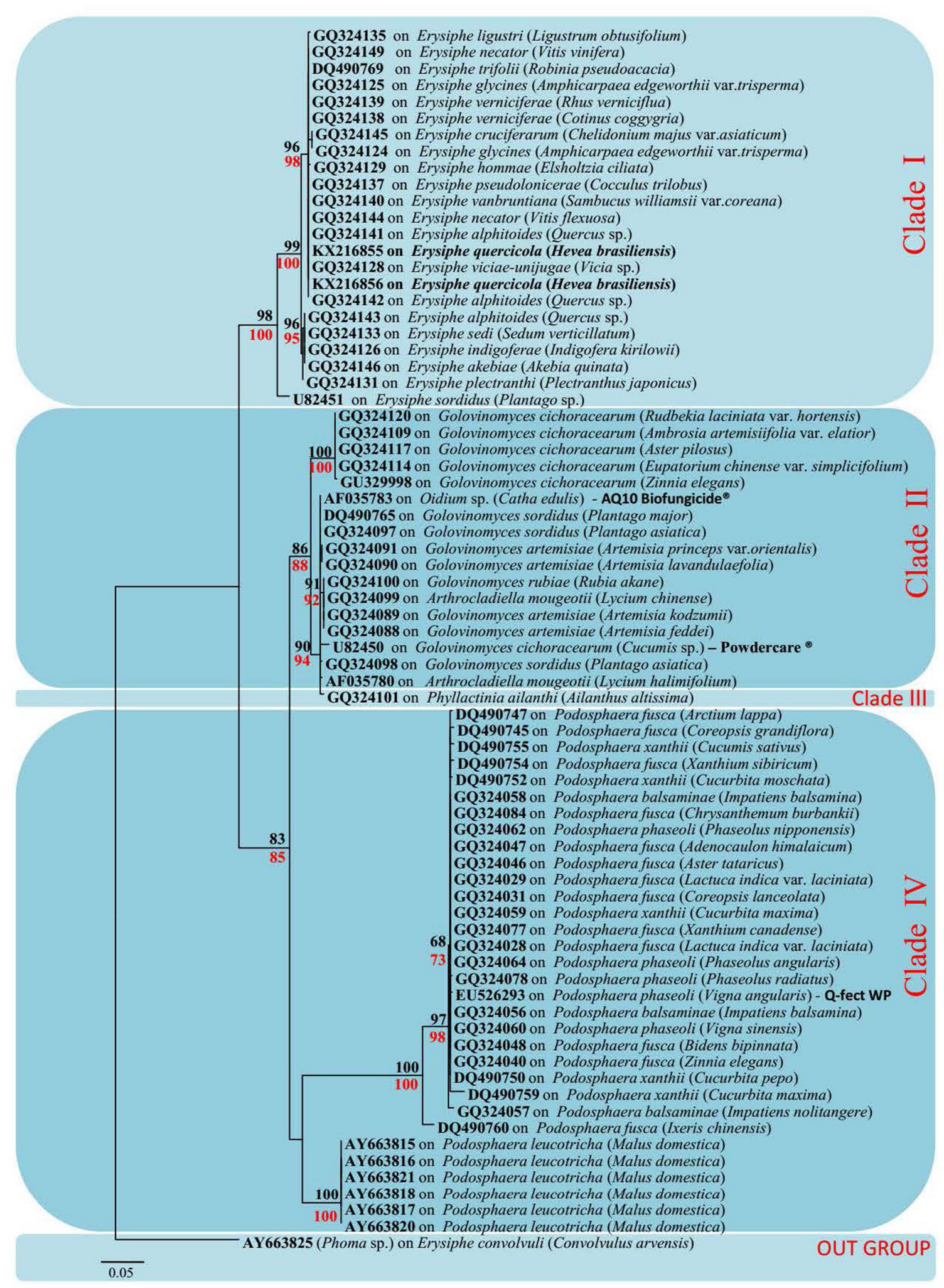

FIGURE 3 | Maximum-likelihood (ML) tree based on a dataset of ITS sequences. Bootstrap support (BS) values for (ML, black) and maximum parsimony (MP, red) higher than $60 \%$ are defined as above the nodes. The tree is rooted to Phoma sp. (All mycohost species associated with Ampelomyces spp. are listed along with the GenBank accession number. The host plant for different mycohosts is presented in brackets. Sequences generated from this study are presented in bold text). 
TABLE 1 | List of haplotypes with their host species, country of origin, and GenBank accession numbers.

\begin{tabular}{|c|c|c|c|c|}
\hline Haplotype & No. of samples & GenBank accession no. & Host species & Country of origin \\
\hline $\mathrm{H} 1$ & 15 & $\begin{array}{l}\text { GQ324145, GQ324124, GQ324139, GQ324138, } \\
\text { GQ324137, GQ324140, GQ324141, GQ324142, } \\
\text { GQ324144, GQ324149, DQ490769, GQ324125, } \\
\text { GQ324128, KX216855, KX216856 }\end{array}$ & Erysiphe & South Korea, China \\
\hline $\mathrm{H} 2$ & 1 & DQ490759 & Podosphaera & China \\
\hline H3 & 16 & $\begin{array}{l}\text { GQ324029, GQ324028, GQ324046, GQ324040, } \\
\text { GQ324031, GQ324077, GQ324047, GQ324084, } \\
\text { GQ324048, DQ490750, GQ324060, GQ324062, } \\
\text { GQ324059, GQ324064, GQ324058, GQ324056 }\end{array}$ & Podosphaera & South Korea \\
\hline $\mathrm{H} 4$ & 1 & DQ490747 & Podosphaera & China \\
\hline H5 & 1 & DQ490754 & Podosphaera & China \\
\hline H6 & 1 & DQ490760 & Podosphaera & China \\
\hline $\mathrm{H} 7$ & 1 & DQ490745 & Podosphaera & China \\
\hline H8 & 1 & DQ490755 & Podosphaera & China \\
\hline H9 & 1 & DQ490752 & Podosphaera & China \\
\hline $\mathrm{H} 10$ & 1 & GQ324078 & Podosphaera & South Korea \\
\hline $\mathrm{H} 11$ & 1 & GQ324057 & Podosphaera & South Korea \\
\hline $\mathrm{H} 12$ & 5 & $\begin{array}{l}\text { AY663815, AY663818, AY663817, AY663816, } \\
\text { AY663820 }\end{array}$ & Podosphaera & $\begin{array}{l}\text { Hungary, Germany, } \\
\text { United Kingdom }\end{array}$ \\
\hline $\mathrm{H} 13$ & 1 & AY663821 & Podosphaera & Hungary \\
\hline $\mathrm{H} 14$ & 1 & GU329998 & Golovinomyces & South Korea \\
\hline $\mathrm{H} 15$ & 4 & GQ324114, GQ324117, GQ324120, GQ324109 & Golovinomyces & South Korea \\
\hline $\mathrm{H} 16$ & 4 & GQ324100, GQ324088, GQ324089 GQ324099 & Golovinomyces & South Korea \\
\hline $\mathrm{H} 17$ & 2 & GQ324091, GQ324090 & Golovinomyces & South Korea \\
\hline $\mathrm{H} 18$ & 3 & GQ324097, DQ490765, AF035783 & $\begin{array}{l}\text { Golovinomyces, Oidium } \\
\text { sp. (AQ10) }\end{array}$ & $\begin{array}{l}\text { South Korea, Germany, } \\
\text { Israel }\end{array}$ \\
\hline $\mathrm{H} 19$ & 1 & GQ324098 & Golovinomyces, & South Korea \\
\hline $\mathrm{H} 2 \mathrm{O}$ & 1 & GQ324129 & Erysiphe & South Korea \\
\hline $\mathrm{H} 21$ & 1 & GQ324135 & Erysiphe & South Korea \\
\hline $\mathrm{H} 22$ & 1 & AF035780 & Arthrocladiella & Hungary \\
\hline $\mathrm{H} 23$ & 1 & GQ324101 & Phyllactinia & South Korea \\
\hline $\mathrm{H} 24$ & 1 & U82451 & Golovinomyces & Germany \\
\hline $\mathrm{H} 25$ & 4 & GQ324126, GQ324133, GQ324146, GQ324143 & Erysiphe & South Korea \\
\hline $\mathrm{H} 26$ & 1 & GQ324131 & Erysiphe & South Korea \\
\hline $\mathrm{H} 27$ & 1 & U82450 & Erysiphe & Germany \\
\hline $\mathrm{H} 28$ & 1 & EU526293 & Sphaerotheca & NA \\
\hline
\end{tabular}

Sequences generated from this study are in bold text, NA, not available.

spp. infecting rubber powdery mildews were hyaline, and the pycnidia and spores were pale brown in color. However, Lee et al. (2007) and Angeli et al. (2011) noted color variations in the mycelium and pycnidia from olive green to pale and dark brown in different mycohosts belonging to the genus Erysiphe. Pycnidia and spores were comparatively smaller in specimens of Ampelomyces isolated from rubber powdery mildews than in specimens isolated from other mycohosts in the same genus (Angeli et al., 2011).

The phylogenetic tree generated by our analyses contains four distinct Clades (Figure 3). Clade I includes all Ampelomyces spp. that infect Erysiphe spp. mycohosts. The specimens collected by the authors from rubber trees also clustered in Clade I with $100 \%$ bootstrap support. They cluster in Clade I because of the rubber powdery mildew also caused by a common fungal species E. quercicola, which belongs to genus Erysiphe (Limkaisang et al., 2005; Takamatsu et al., 2007). The majority of the mycohosts in Clade II belong to genus Golovinomyces. Some Ampelomyces spp. specimens, which infect fungi of genus Arthrocladiella also, clustered along with the genus Golovinomyces, indicating the similarities of their sequences to the mycoparasite in genus Golovinomyces. Although we used one specimen of Ampelomyces sp. that had infected the genus Phyllactinia, it is clustered separately in Clade III in the ML tree, indicating its genetic divergence. Clade IV includes all the Ampelomyces spp., which parasitizes Podosphaera spp. The clustering patterns of Ampelomyces spp. into different mycohost groups provide evidence for narrow host specialization within the A. quisqualis complex. Ampelomyces spp. are sometimes confused with Phoma spp., which are another pycnidial mycoparasites of powdery mildews. According to Kiss and some of his co-workers, Phoma spp. were fast growing and Ampelomyces spp. were slow-growing (Kiss, 1998; Kiss and Nakasone, 1998; Angeli et al., 2011). However, Kiss (1998) pointed out that these two taxa were not 


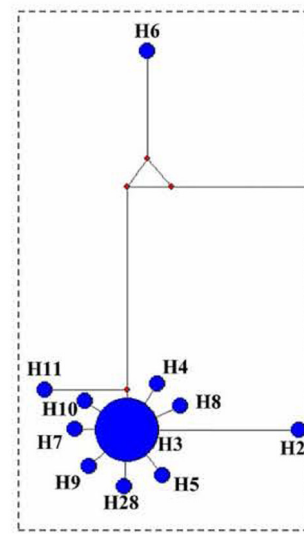

Clade II

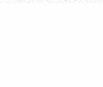

\section{Clade III}

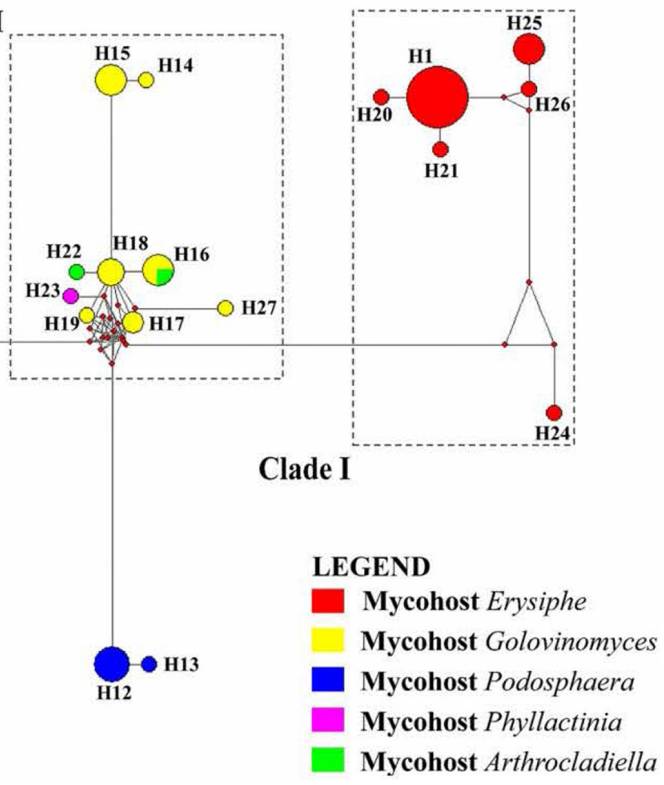

FIGURE 4 | A network of 28 haplotypes of the ITS sequences of 74 Ampelomyces spp. from different mycohost genera. Clades are separated based on their mycohost. Lengths of the branches are proportional to the number of mutation points. The size of each circle is proportional to the frequency of that particular haplotype.

closely related and possibly not congeneric. Therefore, Phoma sp. (AY663825) was used as an outgroup taxon for this analysis.

The ML tree and haplotype network revealed some similar relationships of clustering pattern. The haplotypes $\mathrm{H} 1, \mathrm{H} 20, \mathrm{H} 21$, $\mathrm{H} 24, \mathrm{H} 25$, and $\mathrm{H} 26$ in network tree (Clade I) was similar to the clade 1 of the ML tree, and were associated with genus Erysiphe. In Clade I, H1 was the most dominant haplotype. The Ampelomyces spp. isolated from rubber powdery mildew also clustered in $\mathrm{H} 1$. This indicates that the sequence similarities of different isolates of Ampelomyces spp. to the rubber powdery mildew that cluster together in haplotype group H1. Remaining haplotypes of the Clade I in network tree was generated by creating mutation events of their sequences from the dominant haplotype $\mathrm{H} 1$. The haplotypes $\mathrm{H} 2, \mathrm{H} 3, \mathrm{H} 5-\mathrm{H} 11$, and $\mathrm{H} 28$ are in cluster IV in network tree also clustered similarly in Clade IV of MP tree belong the Ampelomyces spp. which was associated with Podosphaera sp. Haplotype $\mathrm{H} 3$ is the most dominant haplotype in this cluster and includes 16 specimens of Ampelomyces spp. used in this analysis. Similarly, haplotypes $\mathrm{H} 14-\mathrm{H} 19, \mathrm{H} 22, \mathrm{H} 23$, and $\mathrm{H} 27$ make a separate cluster in the haplotype network related to cluster II of the ML tree; this haplotype cluster includes Ampelomyces spp. associated with the mycohost group Golovinomyces spp. The phylogenetic tree also reveals that Ampelomyces spp. clusters together with mycohost Arthrocladiella spp. and Golovinomyces spp. The Ampelomyces spp. in mycohost Arthrocladiella spp. forms a sub-clade with Golovinomyces sp. and this indicates a series of mutation events have occurred. The Ampelomyces spp. in mycohost Phyllactinia was formed a sub-clade from mycohost Golovinomyces spp in network tree after having a one mutation event and therefore, cluster separately in clade III of ML tree. The haplotypes H12 and
H13 were grouped separately in the network tree; in the ML tree, however, they grouped in the same cluster (Clade IV) along with the mycohost Podosphaera spp. This is because Ampelomyces spp. on haplotypes $\mathrm{H} 12$ and $\mathrm{H} 13$ are of European origin (Table 1) and the other haplotypes in clade IV are of Asian origin: mutations and geographic isolation has resulted in new speciation events.

After evaluating both the network tree and ML tree, haplotype analysis of ITS rDNA sequences revealed a distinct genetic lineage among specimens of Ampelomyces spp. These results further confirmed the conclusion of many previous authors (Lee et al., 2007; Park et al., 2010; Angeli et al., 2011). Although a single name is used for this species complex, Ampelomyces spp. is not in fact a single species. In order to address this problem, it will be necessary to conduct detailed morpho-molecular analyses with a large number of isolates associated with different mycohosts. The specimens isolated from rubber powdery mildew were clustered with the haplotype group $\mathrm{H} 1$ in the network tree with 13 other Ampelomyces spp. on mycohosts genus Erysiphe. This indicate that the possibility of use either one of the species in the haplotype group $\mathrm{H} 1$ as an effective microparasite for control the rubber powdery mildew. However, further research, including field trials, will be needed in order to confirm the effectiveness of these potential biocontrols. The commercial products "Q-fect" clustered in Clade IV with other Podosphaera spp. and "AQ10 Biofungicide ${ }^{\circledR}$ " and "Powdercare ${ }^{\circledR}$ "clustered in Clade II with mycohost genus Golovinomyces indicating that sequence similarities of the mycoparasite used to produce these commercial products to their particular genes. These results showed that these biopesticides are not ideal compound to control a wide range of powdery mildews. Identifying particular biocontrol agents which can target different powdery mildew 
groups is likely to bring rubber growers improved results in disease control. The further isolation, culturing, extraction, and investigation of the efficiency of different Ampelomyces species are essential to this effort. In addition, it will be necessary to perform both laboratory and field level experiments to investigate factors such as biocontrol application timing, inoculation potential, and the effect of environmental factors such as temperature and humidity on the growth of particular Ampelomyces sp. Such research could result in the development of a cost effective, environmentally safe alternative method of controlling the devastating rubber powdery mildew disease.

\section{AUTHOR CONTRIBUTIONS}

JX and $\mathrm{KH}$ conceived the original project and research plan. KL and SK designed and performed experiments. PM supervised most of the experiments. SB and SCK provide technical assistance. PM and SK analyzed the data and wrote the paper

\section{REFERENCES}

Angeli, D., Maurhofer, M., Gessler, C., and Pertot, I. (2011). Existence of different physiological forms within genetically diverse strains of Ampelomyces quisqualis. Phytoparasitica 40, 37-51. doi: 10.1007/s12600-011-0197-x

Bandelt, H. J., Forster, P., and Rohl, A. (1999). Median-joining networks for inferring intraspecific phylogenies. Mol. Biol. Evol. 16, 37-48. doi: 10.1093/ oxfordjournals.molbev.a026036

Beeley, F. (1933). O. heveae: report on the 1933 outbreak of Hevea leaf mildew. J. Rubber Res. Inst. Mal. 5, 5-13.

Belsare, S. W., Moniz, L., and Deo, V. B. (1980). The hyperparasite Ampelomyces quisqualis Ces. from Maharashtra State, India. Biovigyanam 6, 173-176.

Chen, Q., Jiang, J. R., Zhang, G. Z., Cai, L., and Crous, P. W. (2015). Resolving the Phoma enigma. Stud. Mycol. 82, 137-217. doi: 10.1016/j.simyco.2015.10.003

Cook, R., Inman, A., and Billings, C. (1997). Identification and classification of powdery mildew anamorphs using light and scanning electron microscopy and host range data. Mycol. Res. 101, 975-1002. doi: 10.1017/S095375629700364X

De S Liyanage, A., and Kuruvilla, J. C. (1992). "Diseases of economic importance in rubber," in Natural Rubber: Biology, Cultivation and Technology, Developments in Crop Science, Vol. 23, eds M. R. Sethuraj and N. M. Mathew (Amsterdam: Elsevier Science), 324-359.

Edgar, R. C. (2004). MUSCLE: multiple sequence alignment with high accuracy and high throughput. Nucleic Acids Res. 32, 1792-1797. doi: 10.1093/nar/gkh340

Emmons, C. W. (1930). Cicinnobolus cesatii, a study in host-parasite relationships. Bull. Torrey Bot. Club 57, 421-441. doi: 10.2307/2480445

Fernando, T. M. (1971). Oidium leaf disease-the effect of environment and control measures on incidence of disease and atmospheric spore concentration. Q. J. Rubber Res. Inst. Ceylon 48, 100-111.

Hall, T. A. (1999). BioEdit: a user-friendly biological sequence alignment editor and analysis program for Windows 95/98/NT. Nucleic Acids Symp. Ser. 41, 95-98.

Hashioka, Y., and Nakai, Y. (1980). Ultrastructure of pycnidial development and mycoparasitism of Ampelomyces quisqualis parasitic on Erysiphales. Trans. Mycol. Soc. Japan 21, 329-338.

Hirata, T., and Takamatsu, S. (1996). Nucleotide sequence diversity of rDNA internal transcribed spacers extracted from conidia and cleistothecia of several powdery mildew fungi. Mycoscience 37, 283-288. doi: 10.1007/BF02461299

Jarvis, W. R., and Slingsby, K. (1997). The control of powdery mildew of greenhouse cucumber by water spray and Ampelomyces quisqualis. Plant Dis. Rep. 61, 728-730.

Jayasinghe, C. K. (2001). "Common disease," in Handbook of Rubber Agronomy, Vol. 1, eds L. M. K. Tillekaratne and A. Nugawela (Agalawatte: Rubber Research Institute of Sri Lanka), 97-105. with contribution of all authors. All authors supervised and complemented the writing.

\section{ACKNOWLEDGMENTS}

This work was supported by Key Research Program of Frontier Sciences, CAS, grant no. QYZDY-SSW-SMC014. We would like to thank the National Science Foundation of China (NSFC) for funding this work under the project codes $41761144055,41771063,31750110478,31650410651$, and 31550110215. This work was partially supported by Mushroom Research Foundation, Chiang Rai, Thailand, Rakan Penyelidikan University, Malaysia (grant no. CG037-2013). We also thank Mr. Andrew Stevenson, World Agroforestry Centre (ICRAF), East and Central Asia, Kunming, Yunnan, China for English editing of the manuscript. KL thanks M. K. Meegahakumbura, Ew Chayanard, Hasini Ekanayake, and Saowaluck Tibpromma for their valuable suggestions and numerous supports extended during the study.

Jayasinghe, C. K., and Jayaratne, R. (1997). Impact of management strategies of Hevea diseases on the environment. Bull. Rubber Res. Inst. Sri Lanka 35, 19-21.

Katoh, K., and Standley, K. (2013). MAFFT multiple sequence alignment software version 7: improvements in performance and usability. Mol. Biol. Evol. 30, 772-780. doi: 10.1093/molbev/mst010

Kishino, H., and Hasegawa, M. (1989). Evaluation of the maximum likelihood estimate of the evolutionary tree topologies from DNA sequence data, and the branching order in hominoide. J. Mol. Evol. 29, 170-179. doi: 10.1007/ BF02100115

Kiss, L. (1997). Genetic diversity in Ampelomyces isolates, hyperparasites of powdery mildew fungi, inferred from RFLP analysis of the rDNA ITS region. Mycol. Res. 101, 1073-1080. doi: 10.1017/S0953756297003705

Kiss, L. (1998). Natural occurrence of Ampelomyces intracellular mycoparasites in mycelia of powdery mildew fungi. New Phytol. 140, 709-714. doi: 10.1046/j. 1469-8137.1998.00316.x

Kiss, L. (2003). A review of fungal antagonists of powdery mildews and their potential as biocontrol agents. Pest Manag. Sci. 59, 475-483. doi: 10.1002/ps.689

Kiss, L. (2008). "Intracellular mycoparasites in action: interactions between powdery mildew fungi and Ampelomyces," in British Mycological Society Symposia Series, Vol. 27, eds L. Boddy, J. C. Frankland, and P. van Wes (Cambridge, MA: Academic Press).

Kiss, L., and Nakasone, K. K. (1998). Ribosomal DNA internal transcribed spacer sequences do not support the species status of Ampelomyces quisqualis, a hyperparasite of powdery mildew fungi. Curr. Genet. 33, 362-367. doi: 10.1007/ s002940050348

Kiss, L., Russell, J., Szentiványi, O., Xu, X., and Jeffries, P. (2004). Biology and biocontrol potential of Ampelomyces mycoparasites, natural antagonists of powdery mildew fungi. Biocontrol Sci. Technol. 14, 635-651. doi: 10.1080/ 09583150410001683600

Kiss, L., and Vajna, L. (1995). "New approaches in the study of the genus Ampelomyces, hyperparasites of powdery mildew fungi," in Environmental Biotic Factors in Integrated Plant Disease Control, ed. M. Manka (Poland: Polish Phytopathological Society), 301-304.

Kohli, D. K., and Bachhawat, A. K. (2003). CLOURE: clustal output reformatter, a program for reformatting ClustalX/ClustalW outputs for SNP analysis and molecular systematics. Nucleic Acids Res. 31, 3501-3502. doi: 10.1093/nar/ gkg502

Kusaba, M., and Tsuge, T. (1995). Phylogeny of Alternaria fungi known to produce host-specific toxins on the basis of variation in internal transcribed spacers of ribosomal DNA. Curr. Genet. 28, 491-498. doi: 10.1007/BF00310821

Lee, S. Y., Hong, S. K., Kim, Y. K., and Kim, H. G. (2007). Selection and identification of a hyperparasite, Ampelomyces quisqualis 94013 for biocontrol 
of cucumber powdery mildew. Korean J. Mycol. 35, 121-127. doi: 10.4489/KJM. 2007.35.2.121

Librado, P., and Rozas, J. (2009). DnaSP v5: a software for comprehensive analysis of DNA polymorphism data. Bioinformatics 25, 1451-1452. doi: 10.1093/ bioinformatics/btp187

Lim, T. M. (1982). Fogging as a technique for controlling rubber leaf diseases in Malaysia and Brazil. Planter 58, 197-212.

Limkaisang, S., Kom-un, S., Fertado, E. L., Liew, K. W., Salleh, Y. S., and Takamatsu, S. (2005). Molecular phylogenetic and morphological analysis of $O$. heveae, a powdery mildew of rubber tree. Mycoscience 46, 220-226. doi: 10.1007/S10267-005-0238-8

Liyanage, K. K., Khan, S., Brooks, S., Mortimer, P. E., Karunarathna, S. C., Xu, J., et al. (2017). Taxonomic revision and phylogenetic analyses of rubber powdery mildew fungi. Microb. Pathog. 105, 185-195. doi: 10.1016/j.micpath.2017. 01.054

Liyanage, K. K., Khan, S., Mortimer, P. E., Hyde, K. D., Xu, J., Brooks, S., et al. (2016). Powdery mildew disease of rubber tree. For. Pathol. 46, 90-103. doi: $10.1111 /$ efp. 12271

Mhaskar, D. N., and Rao, V. G. (1974). The mycoparasite Ampelomyces quisqualis Ces. in artificial culture II. Effect of environmental factors. Phytopathol. Mediterr. 13, 147-154.

Min, T., Haibin, C., Aihua, S., and Huisun, H. (2012). In vitro culture method of powdery mildew (O. heveae Steinmann) of Hevea brasiliensis. Afr. J. Biotecnol. 11, 13167-13172. doi: 10.5897/AJB12.864

Mitra, M., and Mehta, P. R. (1938). Some leaf diseases of Hevea brasiliensis new to India. Indian J. Agric. Sci. 8, 185-188.

Murray, R. K. S. (1930). Sulphur dusting as a means of controlling Oidium. Q. Circ. Rubber Res. Scheme 2, 28-30.

Park, M. J., Choi, Y. J., Hong, S. B., and Shin, H. D. (2010). Genetic variability and mycohost association of Ampelomyces quisqualis isolates inferred from phylogenetic analyses of ITS rDNA and actin gene sequences. Fungal Biol. 114, 235-247. doi: 10.1016/j.funbio.2010.01.003

Priyadarshan, P. M., Hoa, T., Huasun, H., and de Gonçalves, P. S. (2005). Yielding potential of rubber (Hevea brasiliensis) in sub-optimal environments. J. Crop Improv. 14, 221-247. doi: 10.1300/J411v14n01_10

Silvestro, D., and Michalak, I. (2012). raxmlGUI: a graphical front-end for RAxML. Org. Divers. Evol. 12, 335-337. doi: 10.1007/s13127-011-0056-0

Speer, E. O. (1978). Beitrag zur morphologie von Ampelomyces quisqualis Ces. Sydowia 31, 242-246.

Stamatakis, A. (2006). RAxML-VI-HPC: maximum likelihood-based phylogenetic analyses with thousands of taxa and mixed models. Bioinformatics 22, 2688-2690. doi: 10.1093/bioinformatics/btl446
Steinmann, A. (1925). De Ziekten en Plagen van Hevea brasiliensis in NederlandschIndie. Buitenzorg: Buitenzorg Archipel Druklcesij, 90-92.

Sullivan, R. F., and White, J. F. (2000). Phoma glomerata as a mycoparasite of powdery mildew. Appl. Environ. Microbiol. 66, 425-427. doi: 10.1128/AEM.66. $1.425-427.2000$

Swofford, D. L. (2002). PAUP: Phylogenetic Analysis Using Parsimony. Version 4.0 b10. Sunderland, MA: Sinauer Associates.

Szentiványi, O., and Kiss, L. (2003). Overwintering of Ampelomyces mycoparasites on apple trees and other plants infected with powdery mildews. Plant Pathol. 52, 737-746. doi: 10.1111/j.1365-3059.2003.00937.x

Szentiványi, O., Kiss, L., Russell, J. C., Kovács, G. M., Varga, K., Jankovics, T., et al. (2005). Ampelomyces mycoparasites from apple powdery mildew identified as a distinct group based on single-stranded conformation polymorphism analysis of the rDNA ITS region. Mycol. Res. 109, 429-438. doi: 10.1017/ S0953756204001820

Takamatsu, S., Braun, U., Limkaisang, S., Kom-un, S., Sato, Y., and Cunningto, J. H. (2007). Phylogeny and taxonomy of the oak powdery mildew Erysiphe alphitoides sensu lato. Mycol. Res. 111, 809-826. doi: 10.1016/j.mycres.2007. 05.013

Tang, J. K. (2005). Productive control trial on Hevea powdery mildew in heavy popularity year. J. Agric. Sci. Technol. 28, 41-42.

Walsh, P. S., Metzger, D. A., and Higuchi, R. (1991). Chelex 100 as a medium for simple extraction of DNA for PCR-based typing from forensic material. Biotechniques 10, 506-513.

White, T. J., Bruns, T., Lee, S., and Taylor, J. (1990). "Amplification and direct sequencing of fungal ribosomal RNA genes for phylogenetics," in PCR Protocols: A Guide to Methods and Applications, eds M. A. Innis, D. H. Gelfand, J. J. Sninsky, and T. J. White (New York, NY: Academic Press), 315-322.

Conflict of Interest Statement: The authors declare that the research was conducted in the absence of any commercial or financial relationships that could be construed as a potential conflict of interest.

The reviewer CA and handling editor declared their shared affiliation.

Copyright (c) 2018 Liyanage, Khan, Brooks, Mortimer, Karunarathna, Xu and Hyde. This is an open-access article distributed under the terms of the Creative Commons Attribution License (CC BY). The use, distribution or reproduction in other forums is permitted, provided the original author(s) or licensor are credited and that the original publication in this journal is cited, in accordance with accepted academic practice. No use, distribution or reproduction is permitted which does not comply with these terms. 